\title{
A MODERNA POLÍTICA DOS CASTIGOS: UMA PERSPECTIVA DA PUNIÇÃO EM MICHEL FOUCAULT
}

\author{
Daniel de Souza Lemos*
}

\section{INTRODUÇÃO}

O presente artigo pretende abordar o conceito de punição, presente na obra do filósofo francês Michel Foucault, a partir das transformações que tal idéia sofreu, com repercussões em todo o Ocidente, especialmente a partir do século XVIII, tomando-se como modelo a sua ocorrência na Sociedade Francesa.

Para isso procedeu-se à análise de obras relevantes do Pensador estudado, especialmente aquelas em que o mesmo aborda, de forma mais direta, a questão ora examinada. A pesquisa teve como foco inicial a obra "Vigiar e Punir - História da Violência nas Prisões", escrita em 1975, especialmente a sua segunda parte, "Punição", em que Foucault, no capítulo segundo, trata da "Punição Generalizada".

Além disso, também foram utilizadas, especialmente no segundo capítulo do presente trabalho, as obras: "Resumo dos cursos do Collège de France (1970-1982)", publicada inicialmente em 1994 como parte da obra "Dits et Écrits" (4 volumes), e também “Um Dialogo sobre el Poder y Otras Conversaciones", obra publicada na

\footnotetext{
*Mestrando em Ciência Política do Programa de Pós-Graduação em Ciência Política da Universidade Federal de Pelotas (UFPEL). Instituto de Filosofia, Sociologia e Política (IFISP). Bolsista da FAPERGS/CAPES. Graduado em História pela mesma instituição de ensino. Contato: danielslemos@yahoo.com.br
} 
Espanha, no ano de 1982, especialmente o segundo capítulo, “A Propósito Del Encierro Peninteciario".

Outra obra igualmente significativa, para a fundamentação do presente estudo é a “Microfísica do Poder", publicada inicialmente em 1979, principalmente o seu Capítulo VIII, "Sobre a Prisão". Trata-se de uma entrevista de Foucault publicada originalmente no "Magazine Littéraire".

Além das obras citadas que fundamentam mais densamente o presente trabalho, utilizaram-se subsidiariamente outras publicações de Foucault como, por exemplo, "A Verdade e as Formas Jurídicas", "Michel Foucault e seus Contemporâneos”, "Espaços de Poder", "Nietzsche, Freud e Marx. Theatrum Philosoficum" e "Eu, Pierre Rivière, que degolei minha mãe, minha irmã e meu irmão".

Sobre esta última obra cabe salientar, que o conjunto de documentos que lhe serviram de base histórico-informativa relata um episódio de matricídio e fratricídio ocorrido no século XIX. É a história do jovem Pierre, de 21 anos, que, para livrar o pai de uma mulher má (sua própria mãe), mata, degolando-os a golpes de um podão, metade de sua família. Depois de executar os crimes, o jovem Pierre foge para os bosques até ser capturado e levado à julgamento. Preso, Pierre Rivière escreve um Memorial com todos os detalhes e por quês do crime. Mesmo recebendo o perdão do Rei (contra a pena de morte), o jovem Pierre se suicida na prisão como maneira de expiar a sua culpa.

No que concerne à sua estrutura, o texto é dividido em três partes. Na primeira “A SOCIEDADE E A PUNIÇÃO, A Europa do Séc. XVIII" - estuda-se a transformação pela qual passou a prática punitiva no final do século XVIII, deixando de ter como orientação teórica a idéia do suplício, para, paulatinamente, ser substituída pelo aprisionamento dos corpos. Especialmente, tendo como referência as idéias dos "reformadores" (filósofos iluministas) da época estudada. 
Na segunda parte - "A SOCIEDADE PUNITIVA" - é feita uma avaliação histórica das diversas formas como diferentes sociedades lidaram com a questão das táticas punitivas.

Finalmente, na terceira parte - “A JUSTIÇA E A PUNIÇÃO” - analisa-se a profunda relação que a questão da justiça tem com as práticas punitivas. Nesse aspecto destacam-se os debates a respeito da criação do sistema Panóptico e a questão dos Tribunais e da Justiça Popular, que é elogiada por Foucault.

$\mathrm{Na}$ conclusão aborda-se a evolução do conceito de punição a partir de todos os elementos estudados, ao longo do trabalho, ou seja, transformações ocorridas na sociedade européia durante o século XVIII, e início do século XIX, as distintas formas de punição utilizadas por diversas sociedades ao longo da história e, a profunda relação entre a questão da justiça e da punição.

\section{A SOCIEDADE E A PUNIÇÃO - A Europa do Séc. XVIII}

Conforme Michel Foucault, a partir do Sec. XVIII começa a ganhar volume a posição de resistência contra as formas de punição ancoradas nos suplícios físicos. A sociedade européia estava em busca de formas alternativas do ato de punir, uma outra forma de penalização que viesse a distanciar o soberano do condenado, já que, no modelo então vigente, mas ultrapassado, achavam-se muito próximos - refira-se a situação de proximidade física entre o supliciado e o carrasco, este último, na sua posição de legítimo representante do poder então instituído, o poder do soberano.

Segundo a posição do pensador francês, diante do ponto-de-vista do povo, as punições físicas, realizadas em praça pública, representavam a crueldade, a tirania e a sede de vingança do soberano. Esse ato passou, em um curto espaço de tempo, a ser intolerável e inaceitável. Demonstrava um cruel prazer de punir, um excesso extremamente desnecessário. 
Nessa situação, o condenado transformava-se em vítima que fora abandonada por Deus e também pela Justiça: uma vítima reduzida ao desespero, perante um povo amedrontado e consternado com tamanhas injustiças. Diante desse sentimento coletivo torna-se perigoso para o soberano continuar reproduzindo tal maneira de punição, pois está visível a confrontação da violência do Rei com os anseios do Povo, o que levaria este a responder da mesma forma, ou seja, também com violência. Foucault cita Lachèze - membro da Assembléia Constituínte, durante a fase de mesmo nome da Revolução Francesa, em discurso de 03 de junho de 1791: acostumado a ver correr sangue, o povo aprende rápido que só pode se vingar com sangue.(FOUCAULT, 2010, P.70)

No contexto revolucionário e de reformas do Séc. XVIII, reclamava-se uma nova justiça criminal que punisse no lugar de vingar-se, como tinha acontecido até então. Passa-se a exigir que o Estado se dispa da tirania despótica que coloca entre si e o povo, a figura sinistra do carrasco. Essa transformação, de parte do Estado, impõe-se para que o exercício do poder, não deixe de ter legitimidade diante de quem lhe constitui, a saber, o povo.

Nos tempos da Revolução Francesa, inspirada nos ideais iluministas de um novo humanismo, entrou em voga a idéia segundo a qual, mesmo no pior dos assassinos, era fundamental que a sociedade respeitasse, quando do momento da punição, sua humanidade. Essa nova postura, necessária, deveria ser materializada mediante uma penalidade desprovida de qualquer forma de supliciamento. O limite de direito, a fronteira do poder de punir será, a partir de então, o homem que Foucault chama de "homem-medida", ou "homem-limite", medida de poder, diferente de medida das coisas.

Foucault questiona-se acerca do momento em que o "homem-limite" (FOUCAULT, 2010, p.72) ganhou essa condição de referencia no que ele chama de "economia dos castigos" (FOUCAULT, 2010, p.72)? Ele, então, situa esse momento histórico durante o movimento de reforma do Século XVIII, onde alguns "grandes 


\section{Revista Eletrônica \\ Tos Pós Graduandos \\ 1 eSE $\begin{aligned} & \text { em Sociologia Política } \\ & \text { da UFSC }\end{aligned}$}

pensadores"(Beccaria, Servan, Dupaty ou Lacretelle, entre outros) teriam gravado em suas teorias uma suavidade no aparato judiciário, especialmente defendido na obra "Réfutation Du Traité des Delits et des Peines, 1766", de Muyart de Vouglants.

No decorrer de suas pesquisas sobre o momento histórico em que se efetiva o afrouxamento da penalidade, no século XVIII, Foucault aponta que os historiadores ao estudarem os arquivos judiciários franceses perceberam, já desde o fim do século XVII, uma diminuição do que chamam de "crimes de sangue" e das agressões físicas. Por outro lado, os crimes contra a propriedade ganharam relevância, e prevaleceram sobre as outras formas de infração penal.

Os criminosos, na virada do século XVII para o XVIII foram induzidos a mudar suas formas de atuação. Eles passaram a agir de maneira mais matreira e calculada. A delinquência tornara-se mais hábil, menos levada pelos impulsos da cólera. Ao mesmo tempo, os grandes bandos de malfeitores, as tropas de contrabandistas tendiam a se dissociar. As operações mais furtivas, com menor demonstração de força e menores riscos, ganharam importância e aumentaram numericamente.

Observa-se, portanto, um movimento da ilegalidade que Foucault identifica como "ataque aos corpos" para um ataque mais ou menos direto "aos bens". Ele aponta a redução da tensão que reinava nas relações humanas, ao mesmo tempo em que há um controle mais significativo sobre os impulsos violentos. Conclui que houve um afrouxamento dos crimes ou, uma suavização deles, antes do afrouxamento das leis.

Michel Foucault cita outro autor que estudou o mesmo fato histórico, e expõe outros eventos que contribuíram para toda essa mudança na forma de se encarar a punição, na virada do século:

Essa transformação não pode ser separada de vários processos que lhe armam uma base; e em primeiro lugar, como nota P. Chaunu, de uma modificação no jogo das pressões econômicas, de uma elevação geral do nível de vida, de um forte crescimento demográfico, de uma multiplicação das riquezas e das propriedades e da necessidade de segurança que é uma conseqüência disso (FOUCAULT, 2010, p.74). 
Por outro lado, apesar de se constatar uma mudança na forma de se encarar o crime, havendo inclusive o desenvolvimento de ações que impediam o desenvolvimento de uma criminalidade organizada, esse não era o sentimento social de então. Apesar da administração da justiça ter-se tornado mais intensa e mais severa, da legislação ter sido renovada e agravada varias vezes, do exercício da atividade policial ser melhorada e tornar-se mais meticulosa, havia a crença generalizada do aumento incessante e perigoso dos crimes.

A grande transformação do tipo de criminalidade de sangue, essencialmente ancorada na violência, em outra, de fraude, caracterizada pelos crimes contra a propriedade, é parte de um complexo mecanismo. Este é formado por elementos variados destacando-se: o desenvolvimento da produção, o aumento das riquezas materiais, a valorização moral da propriedade, métodos de vigilância mais rigorosos, um policiamento mais intenso da população, entre outros.

Foucault deduz que embora pareça, não se trata de um respeito novo e maior à humanidade dos condenados, mas uma tendência para uma justiça mais “desembaraçada" e mais "inteligente”. Segundo ele, a nova postura em termos da práxis de combate ao crime, produz uma vigilância penal mais eficaz e consistente sobre a sociedade. Há uma maior antecipação das intervenções penais preventivas, pois estas devem impedir os atos delituosos de cunho econômico e também os mais graves com a presença de atos violentos.

Os reformadores apelam por uma nova organização judiciária, pois este "poder" (judiciário) tradicional está degenerado. As razões desta degeneração, segundo o filósofo, obedecem a três eixos fundamentais: "a apropriação privada do juízo"; "a confusão entre as competências de julgar e de legislar"; e "o sistema de privilégios em vigor".A apropriação privada do juízo manifesta-se através da comercialização dos ofícios do juiz, que se transmitem hereditariamente, têm valor comercial e também torna a justiça excessivamente onerosa. 
De outra parte, a confusão existente na mistura de dois tipos de poderes, qual seja, o que presta justiça e formula uma sentença aplicando a lei, e o poder que faz a própria lei. Esse aspecto remete a teoria iluminista de Montesquieu, da divisão dos três poderes que, então, começa a ganhar popularidade, entre os críticos do poder absoluto dos reis.

Esse conjunto de "lacunas", visceralmente entranhados no sistema penal é que vai ser objeto da crítica dos reformadores, conforme Foucault. Essa crítica é constituída menos pela referência à crueldade característica desse sistema, do que por apontar a má economia em termos de poder que significa. Sustenta-se mais por acentuar o desperdício e a ineficácia que representa, do que pela falta de humanismo que lhe é tão peculiar.

Eles atacam, sobretudo, o poder excessivo que possibilita aos juízes serem, ora excessivamente severos, ora indulgentes demais. Assim recusam, fundamentalmente, poderes demais delegados aos agentes do rei bem como poderes excessivos exercidos pelo rei. Isso acaba por suspender o curso da justiça, consagrando o arbítrio como sempre acontecia até então.

$\mathrm{Na}$ interpretação de Michel Foucault, não se trata de uma crítica apenas aos privilégios da justiça absolutista, de sua arbitrariedade, de sua arrogância arcaica, etc., mas a mistura disso tudo, das fraquezas e dos excessos, características desse sistema. Os reformadores, segundo ele, objetivaram menos o anseio de fundar um novo direito de punir baseado em um humanismo oral, na igualdade, e muito mais o de criar um sistema mais "econômico no poder de castigar", e, principalmente, em melhorar a forma de distribuição da punição, enfraquecendo, quiçá extinguindo, os privilégios.

A reforma da justiça criminal, em última instância, o novo modo de ser exercido o poder de punir, deve ser interpretado como uma estratégia de remanejamento que o tornaria mais regular, mais eficaz, mais constante e mais detalhado em seus efeitos. Enfim, o sentido da reforma consiste na melhora dos resultados da ação da justiça criminal, reduzindo-se o dispêndio de caráter econômico, principalmente no que se 
refere aos gastos com a estrutura jurisdicional, bem como na redução de seu custo político, afastando-a do arbitrário poder monárquico.

O produto dessa reforma da justiça criminal e do poder de punição, Foucault denomina-o de "Economia Política do Poder de Punir". Ela não possui um ponto único de origem. A reforma partiu, por um lado, de dentro do próprio sistema penal, de sua rede de contradição interior, dos interesses antagônicos que lhe estavam interiorizados. Mas, por outro lado, recebeu um impulso externo, de agentes sociais que não faziam parte do sistema de justiça, mas que sofria suas conseqüências. Era, de um lado, a movimentação dos próprios magistrados que tinham seus conflitos e disputas de poder, de outro lado, as idéias iluministas dos filósofos da época e, mesmo de advogados militantes que possuíam seus interesses mais objetivos.

Entretanto, essa transformação na maneira de se encarar a punição, conseguiu consolidar-se e a reforma estruturou-se como uma teoria penal e como uma estratégia do poder de punir, graças ao lugar prioritário que ocupou. Nas palavras de Foucault " $a$ nova legislação criminal se caracteriza por uma suavização das penas, uma codificação mais nítida, uma considerável diminuição do arbitrário, um consenso mais bem estabelecido a respeito do poder de punir"'(FOUCAULT, 2010, p.p.85-86).

Em síntese, as razões de ser da reforma penal do século XVIII, tiveram como objetivo a redução dos custos político e econômico da punição. Esse novo estatuto da punição é plenamente adaptado às teorias gerais do contrato tão características dos pensadores iluministas. Supõe-se que o cidadão tenha aceito o contrato, ao submeter-se às leis da sociedade, que poderá puni-lo. $\mathrm{O}$ criminoso é o sujeito que rompeu o pacto, logo ele entra em conflito com a sociedade inteira que tem legitimidade para castigá-lo.

Portanto, em razão de o criminoso ter rompido o pacto e cometido uma infração, ele entra em conflito com a sociedade inteira e com cada indivíduo. Cabe à sociedade legitimamente puni-lo para defender os direitos de todos e de cada um. O direito de punir desloca-se, assim, da vingança do soberano à defesa da sociedade. 
Além disso, a aplicação da pena passa a ter como referência a desordem que o delito possa trazer ao corpo social: o escândalo que suscita, o exemplo que dá, a incitação de ser repetido, se não for punido adequadamente. O cálculo da pena opera-se em função não do crime, mas de sua possível repetição. Deve visar "não à ofensa passada, mas a desordem futura" (FOUCAULT, 2010, p.89). Está, portanto, no entardecer do século XVIII a origem da nova política econômica punitiva, escorada nos princípios dos reformadores iluministas, e na burguesia em ascensão.

\section{A SOCIEDADE PUNITIVA}

Michel Foucault encontrou quatro formas históricas de táticas punitivas que foram utilizadas, em momentos históricos e sociedades distintas. Essas formas apareceram, inúmeras vezes, mescladas e concomitantes.

A primeira forma, presente nas sociedades gregas, Foucault denomina de sociedades de "banimento". Nelas as táticas punitivas são caracterizadas pelos verbos exilar, rechaçar, banir, expulsar, interditar destruir o lar, apagar da memória, confiscar (bens e propriedades).

A segunda forma, característica dos germânicos, chamadas de sociedades de "resgate", prioriza-se algum tipo de compensação. Impõe-se o resgate, converte-se o dano provocado em uma divida a ser paga, em suma, converte-se o delito em obrigação financeira.

A terceira maneira punitiva, comum no final da Idade Média (nas sociedades ocidentais) são as de "marcagem". O modus operandi pauta-se pelos atos de marcar, ferir, amputar, fazer uma cicatriz, deixar algum sinal no rosto ou no ombro, impor uma diminuição artificial e visível, supliciar, ou seja, apoderar-se do corpo do condenado, de forma nele inscrever as marcas do poder.

Por fim, a quarta maneira punitiva, presente nas sociedades modernas e contemporâneas, é o encarceramento. Porém, a detenção é inserida no sistema penal 
europeu a partir das reformas iluministas do século XVIII. Até então as reclusões praticadas durante os séculos anteriores ao XVIII, estavam à margem do sistema punitivo. Entretanto, posteriormente às reformas iluministas, a prisão torna-se a forma geral e mais comum de penalidade.

Já no começo do século XIX, os teóricos do sistema penal assinalam que o novo sistema de punição é o encarceramento em suas diversas formas. Por outro lado, o novo sistema atraía olhares mais críticos. Muitos diziam que a prisão impede o poder judiciário de controlar e de verificar a aplicação das penas. Além disso, a prisão, ao misturar os condenados, constitui uma comunidade homogênea de criminosos que se tornam solidários no enclausuramento e, também, em seu exterior.

Os críticos do sistema prisional apelam também, para argumentos de classe. Afirmam que dando um abrigo, comida, roupas e trabalho aos condenados, a prisão lhes assegura um destino, por vezes, preferível ao dos operários em geral.

Se por um lado a prisão representou um avanço em direção à humanização da punição, por outro lado foi alvo de críticas tão contundentes como as que lhe deram origem no século XVIII. A prisão é denunciada como um instrumento de fabricação daqueles que a justiça mandará encarcerar uma ou mais vezes.

Em contrapartida deram-se respostas às críticas feitas ao sistema prisional. Destacam-se as discussões em torno do isolamento completo ou parcial dos detentos dentro das prisões, moralização dos condenados através do trabalho, da instrução, da religião, de recompensas, de reduções de penas, entre outras.

Os teóricos do século XIX irão insistir que o encarceramento é a pena por excelência das sociedades civilizadas. Tal tendência é moral quando acompanhada da obrigação do trabalho.Os defensores do sistema prisional irão argumentar que a prisão tem quatro vantagens. A primeira delas é poder dividir-se em diferentes níveis, quantos forem necessários, a gravidade do delito; a segunda é impedir a reincidência; a terceira é permitir a correção; e a quarta é ser a prisão uma penalidade suficientemente leve para permitir que os julgadores não hesitem em aplicá-la. 


\section{Revista Eletrónica \\ In dos Pós Graduandos \\ 1 eSe ${ }_{\text {da UFSC }}^{\text {em Sociol }}$}

De acordo com Foucault, a reclusão desempenha um papel com três características distintas: intervém na distribuição espacial dos indivíduos, intervém na conduta dos indivíduos, não é um instrumento arbitrário do absolutismo.

Conforme assevera o Pensador, referindo-se às penas de reclusão:

O estudo das Lettres de cachets mostra que eram, em sua grande maioria, solicitadas por pais de família, notáveis locais, comunidades locais, religiosas e profissionais liberais contra os indivíduos que lhes provocavam incômodos e causavam desordem (FOUCAULT, 1997, p.37).

O que transformou a penalidade, na virada do século XVIII para o século XIX, foi o ajustamento do sistema judiciário a um mecanismo de vigilância e de controle. Foi a criação de um aparelho de Estado centralizado, baseado no binômio vigilância-reclusão, presente em toda a estrutura do corpo social. A cristalização das sociedades da vigilância ocorre a partir da criação do modelo Panopticon - modelo prisional criado por Jeremy Bentham, jurista inglês, no final do século XVIII.

Essas transformações ocorridas nas sociedades punitivas vinham a atender as necessidades do novo modo de produção, o capitalista que colocava a demanda material da sociedade em outro patamar, além de atribuir um novo status ao domínio da propriedade, conforme foi salientado no capítulo anterior.

Soma-se a isso a necessidade de fixar os trabalhadores ao aparelho de produção, estabelecê-los ou deslocá-los para onde fossem necessários. Daí resulta uma nova legislação, com novos delitos, reguladora do comportamento das classes inferiores.

As conclusões a que chega Foucault: as formas de penalidades surgidas no final do século XVIII não inovam a uma mudança de valores morais. A sociedades punitivas, optam pelo sistema prisional como forma geral de punição e abolição dos suplícios. $\mathrm{O}$ corpo, então, não precisa mais ser marcado.

Além disso o poder político se relaciona de outras formas com os corpos. Seu controle passa a dar-se de outras formas, mais sutis e mais eficientes. É criada uma força policial mais ostensiva e profissionalizada, baseada no sistema do panoptismo. A 


\section{Tmevista Eletrônica T. dos Pós Graduandos \\ 1 eSe em Sociolog}

evolução histórica do conceito de punição está estreitamente ligada à relação do poder político com os corpos. Mais precisamente no que se refere à maneira como o poder é exercido para o domínio, controle, sujeição dos mesmos.

Pode-se situar nesse momento histórico a ordem de crimes e de delinquentes próprios da época atual. É na segunda metade do séc. XVIII que vai aparecer a idéia de que o delinqüente é inimigo de toda a sociedade. Toda uma nova teoria do crime e do delinqüente surge em função disso. Há que se produzir, então, meios de vigiar o povo em geral.

O sistema panóptico configura-se, então, como o maior sonho no sentido de realizar-se a vigilância plena de toda a sociedade, por um único indivíduo. Evidentemente, que o modelo proposto por Bentham, por limitado arquitetonicamente, não se constitui como a realização efetiva do objetivo, mas traduz o caminho e o espírito de tal sistema.

Nas palavras de Foucault:

Vivimos en una sociedad panóptica. Tenemos unas estructuras de vigilância absolutamente generalizadas, de las que el sistema penal, el sistema judicial es una pieza, y de las que la prisión es a su vez uma pieza, y de las que la psicología, la psiquiatría, la criminología, la sociología, la psicología social son los efectos. Es en este punto, en este panoptismo generalizado de la sociedad en donde debe situarse el nacimiento de la prisión (FOUCAULT, 1997, P. 63).

A sociedade punitiva moderna é toda ela fundada na vigilância. Uma vigilância, por assim dizer, generalizada. Ela se estende em setores e instâncias de vigilância: a vigilância médica, a vigilância escolar, a vigilância penal. Em suma, uma vigilância que busca se antecipar ao ato delituoso, que tem como conseqüência lógica a necessidade da punição do delinqüente, inimigo do corpo social. 


\section{A JUSTIÇA E A PUNIÇÃO}

O sentido de uma punição atribuída a algum indivíduo, é o de ser uma resposta a uma agressão pelo mesmo praticada. Tal ofensa pode ser material ou imaterial, pessoal ou coletiva. A punição estava, no passado, vinculada a idéia de vingança. O progresso humano, ao longo da história, foi alterando essa lógica e o que era a vingança pessoal, ou do clã, passou a ser a vingança do corpo social: uma resposta à agressão que agora era sentida por toda a sociedade, por vezes representada apenas por um indivíduo, ao ser desrespeitada uma norma de conduta.

Contudo o ato de desrespeito a uma regra aceita por todos que vivem na sociedade, ensejador de punição, precisava ser medido, avaliada sua veracidade, as dimensões de sua repercussão, o seu potencial ofensivo, daí criando-se a medida do próprio castigo a ser aplicado. Tudo isso foi canalizado para uma figura que deveria ocupar uma terceira posição, em relação ao agressor e ao agredido ou, o eu e a vítima.

Nas revoluções do século XVIII apareceu a figura da justiça popular. $\mathrm{Na}$ Revolução Francesa, o Tribunal Popular, funcionou durante um período como uma terceira instância, bem determinada socialmente. Ele representava uma linha intermediária entre a nova classe social no poder, e a plebe, o povo em geral.

Essa instância judiciária, ocupava, tal qual no Antigo Regime, uma posição mediana. Era o lugar onde se mediavam os conflitos de classe baseados em uma ideologia moral, convenientemente moldada pelas circunstâncias. Nela estava plenamente estabelecida a noção do que era o certo e o errado.

Foi durante a Idade Média que um conjunto de instituições estáveis, específicas e que intervinham de maneira autoritária e dependente do poder político, se estabeleceu como "justiça", no lugar dos Tribunais Arbitrais. Essa transformação apoiou-se em dois mecanismos, conforme Foucault: o primeiro baseado na fiscalização da justiça e o segundo baseado na força policial ou militar. 
Primeiramente a fiscalização da justiça era algo muito lucrativo. Havia uma economia política da justiça, baseada nas multas, nos confiscos, nos sequestros de bens. Nas mãos dos senhores feudais a justiça tornou-se um meio de apropriação e de coerção, ou seja, uma fonte de riqueza; era considerada parte da renda do senhor feudal e um direito seu, herdado.

Nesse aspecto o funcionamento da justiça, quando comparado ao período antigo, inverte-se: antes para aqueles que estavam sob sua jurisdição, era considerado um direito, o de pedir justiça, e dever para os árbitros, ao distribuir a justiça a partir de seu poder ou conhecimento. Na Idade Média observa-se a inversão dessa lógica: o direito torna-se lucrativo para quem detém o poder e oneroso para quem está subordinado a ele.

No segundo mecanismo, a justiça está vinculada totalmente ao poder bélico que apenas o suserano possui. A justiça da paz é a do senhor feudal, imposta por ele. É, também, um meio de onde ele retira seus proventos, seus benefícios e aumenta sua riqueza.

De acordo com Foucault "foi sobre este pano de fundo de guerra social, de extração fiscal e de concentração das forças armadas que se estabeleceu o poder judiciário”. (FOUCAULT, 1979, p.43) É por isso, em seu entendimento, que a lógica da justiça popular, da época da revolução, é totalmente anti-judiciária, contrária à forma tradicional dos tribunais do Antigo Regime.

Portanto, a justiça adquiriu um caráter de instrumento de classe, de dominação de classe. Explicam-se dessa maneira algumas práticas que foram comuns durante a Revolução Francesa na punição dos agentes do estado, como por exemplo, no assalto e no incêndio da Bastilha, ou, ainda, na exposição pública da cabeça decepada de um representante do Rei.

Revivem-se velhos rituais ancestrais, típicos das práticas populares de justiçamento e punições que ocorrem por fora da lógica formal das instâncias judiciárias. Nas palavras de Foucault: 


\title{
Revista Eletrônica Dos Pós Graduandos \\ 1 eSe em Sociolod
}

\begin{abstract}
Parece-me que a história da justiça como aparelho de Estado permite compreender porque, pelo menos na França, os atos de justiça realmente populares tendem a escapar ao Tribunal e por que, ao contrário, cada vez que a burguesia quis impor à sedição do povo a coação de um aparelho de Estado, se instaurou um tribunal: uma mesa, um presidente, assessores e dois adversários em frente. Assim reaparece o judiciário (FOUCALT, 1979, p. 44).
\end{abstract}

Michel Foucault diferencia drasticamente dois tipos de justiça: uma, a dos Tribunais, outra, a Justiça Popular, ambas lidando com a questão da punição. No primeiro encontram-se presentes os elementos básicos daquilo que está cristalizado na cultura, pelo menos do Mundo Ocidental, o segundo baseia-se em outra lógica de justiça.

A simples forma do Tribunal já deduz seus princípios norteadores. Uma mesa, atrás dela um terceiro que está eqüidistante das partes adversárias. Aquele terceiro é a parte neutra, o Juiz, o responsável por dar a sentença, neutra, desinteressada, fundamentada em valores de justo e injusto, numa noção de verdade, cuja opinião não pode ser predeterminada antes das alegações.

No outro lado está a justiça popular: nessa não há três lados, tampouco mediação. Nessa concepção, as massas apenas identificam seus inimigos e os punem ou reeducam. Baseados não em um princípio moral de justo e injusto, de certo e errado mas orientados pela agressão que sofreram, ou pela maneira como foram lesados, ou pela perseguição de que foram objeto. Nessa forma de justiça, as massas não precisam se apoiar em um aparelho do Estado, ou numa instituição. Apenas executam suas formas de punição orientadas pela sua idéia de justiça ou vingança.

A partir das transformações ocorridas no século XVIII, os novos tribunais ganharam novas características que bem mais tarde se consolidaram e os caracterizam atualmente. Não seria mais uma das partes que controlaria a instância judiciária e esta não teria, como finalidade, educar. 
Atualmente o sistema penal apresenta-se como anti-sedicioso, ao tentar opor as classes baixas proletarizadas aos que estão fora das relações de trabalho. A burguesia procurou criar meios de garantir sua segurança contra as classes proletárias. Uma maneira de realizar esse projeto, foi através da justiça, criando mecanismos de separação entre as massas, sendo que as relações de trabalho serviram a esse fim. Uma das principais formas foi através das prisões.

A burguesia, através da justiça, introduziu uma grande separação entre o proletariado e a plebe, ou entre os que estão inseridos no processo produtivo e os que estão excluídos desse processo. Os aparelhos jurídicos assim montados têm efeitos ideológicos específicos sobre cada uma das classes sociais dominadas.

Variadas noções burguesas de justo e injusto, certo e errado, propriedade, roubo, crime e criminoso, foram incutidas na moral proletária. Entretanto essas classes dominadas foram-se moldando ao longo do tempo, sendo absorvidas pelos projetos históricos da burguesia. A plebe sempre foi sendo colocada diante de alternativas morais feitas pela burguesia: prisão ou exército; prisão ou colônia; prisão ou polícia. Todas quesitações tinham um fundo moral e uma alternativa punitiva.

Diante de todas essas construções ideológicas da burguesia acerca da justiça, Foucault constrói uma posição crítica. Em sua posição, todas as idéias da burguesia servem para que essa classe exerça o poder, fazendo a SUA justiça. Em razão disso ele é contrário à idéia de um Tribunal Popular para a realização da justiça.

Afinal, é através dos juízes, dos procuradores e, sobretudo dos intelectuais, que a burguesia tem espalhado e imposto os seus temas ideológicos. Qualquer forma de justiça que funcione à semelhança da justiça burguesa deve ser vista com desconfiança. Foucault desconfia especialmente, do aparelho judiciário e da burocracia do Estado. Em sua opinião o tribunal é a burocracia da justiça.

As formas de punição baseadas na prisão dos corpos, estão fortemente influenciadas pela problemática da justiça burguesa. Os tribunais que têm, consigo, a ideologia da justiça burguesa e as formas de relação entre juiz e julgado, juiz e parte, 
juiz e pleiteante, e aplica essa justiça, têm um papel fundamental na dominação de classe.

O fato de haver um tribunal, onde o litígio das partes estará suspenso e submetido a uma força superior e maior é o suporte necessário para que o estado burguês ganhe a aparência de justo. Segundo o Pensador, é tudo o que a burguesia quer e precisa para impor seus valores, suas crenças, suas opiniões, de forma legitimada e pacífica.

Nesse passo, conclui Foucault que essa forma de justiça deve ser alvo de um duro e incansável embate ideológico por parte das classes dominadas. Uma nova forma de justiça popular deve estar completamente afastada das características da velha justiça burguesa.

Foucault fala abertamente da criação de uma justiça revolucionária uma justiça popular, contraposta à idéia de tribunal popular que remete à lógica dos tribunais tradicionais da burguesia. Uma justiça revolucionária deve ser baseada em novos padrões ideológicos de moralidade que se distanciem da ideologia imposta pela burguesia e elaborada pelos seus serviçais históricos do aparelho judiciário-estatal.

\section{CONSIDERAÇÕES FINAIS}

Após uma análise detida de parte significativa da produção intelectual de Michel Foucault é possível proceder a uma avaliação a respeito de sua idéia sobre o conceito de punição.

Em primeiro lugar é fundamental situar o momento histórico da Revolução Francesa, do final do Século XVIII em que as teorias dos pensadores iluministas que o filósofo trata como "reformadores", ganham uma grande amplitude e sua voz é propagada para fora da Europa e além de seu tempo..

Havia uma intensa necessidade de se encontrar novas maneiras de se fazer justiça, que se afastassem das tradicionais práticas punitivas baseadas nos odiosos suplícios 
físicos. Essa forma de punição estava demasiadamente vinculada à crueldade, à tirania, enfim, à sede de vingança do soberano.

Buscava-se uma forma, no séc. XVIII, de se respeitar a condição humana do criminoso. O ideário Iluminista não mais aceitava as práticas punitivas medievais que tinham os corpos como objeto central de produção de dor e sofrimento. Nesse sistema o próprio criminoso tornava-se uma vítima.

Clamava-se por uma nova justiça criminal que não tivesse como norte a vingança quando fosse aplicar a punição. Por outro lado, também se buscava afastar do poder a tirania do soberano. Este deveria ter outra conduta em relação à prática do poder que lhe havia sido conferido pelo povo.

Na lógica de punir-se sem o uso de métodos sádicos que agredissem os corpos e fossem baseados na lógica do suplício, Foucault identifica uma medida ideal. Esta é o homem, o modelo limite da punição chamado de "homem-limite". O homem como parâmetro para todas as formas de castigo, na melhor tradição iluminista.

Nesse mesmo momento histórico aparece uma lógica, tipicamente burguesa, de produzir uma maneira mais eficiente de se conduzir as punições: seria uma "economia política dos castigos".

Outra mudança, que aparece no mundo dos delitos, apresentada por Foucault foi a diminuição das incidências de "crimes de sangue", em relação a crimes contra a "propriedade". Em decorrência deste fato a legislação criminal é renovada várias vezes, inclusive, no período da Revolução Francesa, destaca-se o debate sobre a reforma penal.

Essas discussões apontam no sentido de alterar-se a própria estrutura da justiça, ao mesmo tempo em que se procura extinguir o uso arbitrário do poder do soberano na distribuição da justiça.

Num segundo momento procedeu-se a um levantamento histórico baseado nos estudos realizados por Foucault, a respeito das diferentes táticas punitivas utilizadas por diferentes sociedades em distintos momentos históricos em que se identificam quatro formas elementares de táticas punitivas utilizadas em distintas sociedades como as 
práticas de banimento, resgate, marcagem e, por último, característica das sociedades contemporâneas, o encarceramento.

Esta última tática punitiva sempre esteve à margem dos sistemas punitivos até o século XVIII. Depois começou a ganhar relevância, a ponto de tornar-se predominante, senão exclusiva, nas sociedades contemporâneas.

Ao mesmo tempo em que se teoriza a respeito da natureza dos crimes e de suas possibilidades de punição, conceituando o criminoso como um inimigo de todo o corpo social, o novo sistema punitivo calcado nas prisões, também é objeto de intensa crítica.

Nesse momento de transformação das práticas de punição baseadas no aprisionamento dos corpos, ocorridas após o séc. XVIII destacam-se duas problemáticas. Uma refere-se à questão da delinqüência produzida dentro dos próprios sistemas prisionais, realidade sentida profundamente nos dias de hoje, e objeto de acirrados debates.

Outra inovação do sistema punitivo prisional foi a criação do sistema Panóptico, modelo criado por Jeremy Bentham, jurista inglês, no final do século XVIII. Apesar de toda essa discussão as formas de penalidades surgidas no final do século XVIII não inovaram na direção de uma mudança de valores morais.

Foucault conclui que a sociedade punitiva moderna é baseada na vigilância generalizada. Ela se estende a setores e instâncias de vigilância. Uma vigilância preventiva do ato delituoso que tem como conseqüência a necessidade da punição do delinqüente, inimigo da sociedade.

Por fim, o Pensador aborda a evolução da punição como uma resposta a uma agressão feita à sociedade que buscava antes a vingança, e agora busca a justiça. Nesse intento ele discute o papel do Estado como o responsável a dizer o que é o justo, fazendo isto através de suas instituições, sendo a mais característica a do tribunal.

Michel Foucault intensamente o papel que os Tribunais desempenharam ao longo do tempo nas diferentes sociedades. Pauta, inclusive seus limites e distorções e 
contrapõe a essas instituições a idéia de Justiça Revolucionária, denunciando as limitações burocráticas e institucionais da justiça burguesa.

Para o Filósofo, uma verdadeira justiça popular deve fundamentar-se numa nova moralidade, em novos valores, diversos da moralidade burguesa.

Evidencia-se, pois que a substituição da lógica da vingança pela resposta justa da agressão sofrida por toda a sociedade, pelo ato ilegal criminoso é um esforço nascido no alvorecer da classe burguesa, no Ocidente, e praticado pelas diversas sociedades, ao longo do tempo, até os dias de hoje.

Apesar do discurso ideológico burguês, acentuando o processo de humanização e de mitigação das punições, na postura moderna das teorias da pena, como obra de uma moralidade que valoriza os direitos humanos, Foucault ressalta a dimensão utilitária, por assim dizer, mais funcional ao sistema, o caráter de classe dos processos de punição e de julgamento, mediante os conceitos de "economia política do crime", de "homemlimite", e de "justiça", enquanto aparelho judiciário, como instrumento de dominação da classe burguesa. Assim consolidaram-se os novos sistemas penais que se ergueram após as reformas do século XVIII.

\section{REFERÊNCIAS}

ERIBON, Didier. Michel Foucault e Seus Contemporâneos. Tradução Lucy Magalhães. Rio de Janeiro: Jorge Zahar Editor, 1996.

FOUCAULT, Michel. A Verdade e as Formas Jurídicas. Tradução Roberto Cabral de Melo Machado e Eduardo Jardin Morais. Rio de Janeiro: Nau Editora, 1999.

. Eu, Pierre Rivière, que degolei minha mãe, minha irmã e meu irmão... um caso de parricídio do século XIX, apresentado por Michel Foucault; tradução de Denize Lezan de Almeida. Rio de Janeiro: Graal, 1977. 
, CASTEL, Robert. ET alli. .Espacios de Poder. Traducción Julia Varela y Fernando Alvarez-Uría. Madri: Las Ediciones de La Pigueta, 1980.

. Microfísica do Poder;Org. e Trad. Roberto Machado. Rio de Janeiro: Edições Graal, 1979.

.Nietzsche, Freud e Marx. Theatro Philosoficum. $4^{\mathrm{a}}$ Ed. Tradução Jorge Lima Barreto. São Paulo: Editora Princípio, 1975.

.Resumo dos Cursos do Collège de France (1970-1982). Tradução Andrea Daher. Rio de Janeiro: Jorge Zahar Edidtor, 1997.

.Un diálogo sobre el poder y otras conversaciones. Introducción y

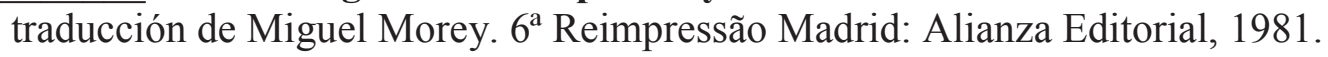

. Vigiar e Punir: nascimento da prisão; Tradução de Raquel Ramalhete. $38^{\mathrm{a}}$ ed. Petrópolis/Rio de Janeiro: Vozes, 2010.

RAJCHMAN, John. Foucault, A Liberdade da Filosofia. Tradução Álvaro Cabral. Rio de Janeiro: Zahar Editor, 1985.

\section{RESUMO}

O presente artigo pretende abordar o conceito de punição, presente na obra do filósofo francês Michel Foucault, a partir das transformações que tal idéia sofreu, com repercussões em todo o Ocidente, especialmente a partir do século XVIII, tomando-se como modelo a sua ocorrência na Sociedade Francesa. Para isso procedeu-se à análise de obras relevantes do pensador estudado, especialmente aquelas em que o mesmo aborda, de forma mais direta, a questão ora examinada. A pesquisa teve como foco inicial a obra "Vigiar e Punir - História da Violência nas Prisões", escrita em 1975, especialmente a sua segunda parte, "Punição", em que Foucault, no capítulo segundo, trata da "Punição Generalizada".

PALAVRAS-CHAVE: Foucault. Castigo. Punição. Violência. Sociedade. 


\begin{abstract}
This article seeks to address the concept of punishment, in the works of French philosopher Michel Foucault, from the transformations suffered such an idea, with repercussions throughout the West, especially from the eighteenth century, taking as its model the occurrence in French Society. For this we proceeded to the analysis of works relevant Thinker studied, especially those in which it addresses more directly the question now under consideration. The research focused on the initial work "Discipline and Punish - History of Violence in Prisons", written in 1975, especially its second part, "Punishment" in which Foucault, in the second chapter deals with the "Generalized Punishment".
\end{abstract}

KEYWORDS: Foucault. Punishment. Violence. Society.

Recebido em: 28 de junho de 2013

Aceito para publicação em: 04 de julho de 2013 